\title{
Genomic mapping of non-coagulation of milk in the Finnish Ayrshire
}

\author{
K. Elo' ${ }^{1}$ A.-M. Tyrisevä, P. Anttila, V. Vilva and M. Ojala \\ Department of Animal Science, University of Helsinki \\ P.O. Box 28, FIN-00014 Helsinki, Finland
}

\begin{abstract}
The objective of this study was to identify chromosomes affecting non-coagulation of milk in the Finnish Ayrshire. All autosomes were analysed using two pools of DNA samples. Samples from cows milking non-coagulating (NC) and well-coagulating (E) milk were pooled. Pools included 33 NC- and 49 E-animals and they were genotyped using 184 microsatellite markers. Two candidate chromosomes, 24 and 28, were selected based on differences between pools. Chromosomes 24 and 28 were studied using 14 microsatellite markers, individual genotyping and daughter design. Nonparametric interval mapping involved eighteen sire families with a total of 480 daughters. In interval mapping, chromosome 24 associated to NC-milk in one family.
\end{abstract}

KEY WORDS: milk coagulation traits, non-coagulation of milk, genetics, DNA markers, curd firmness, cheese yield

\section{INTRODUCTION}

The average percentage of milk used in cheese production is approximately $50 \%$ in the European Union when calculated from production statistics using a 10/L milk to cheese yield ratio (Eurostat, 2006). The high percentage of milk used in cheese production suggests that in many European countries the improvement of raw milk for cheese making should be economically well-motivated. In addition to technological improvements in cheese industry, breeding and management of dairy cattle provide important tools to improve quality of milk for cheese making.

Milk coagulation properties (MCP) are known to play important role in cheese production (Ikonen, 2000; Lucey, 2002). Milk coagulation is dependent on environmental and genetic factors of dairy cows (Ikonen, 2000). In addition,

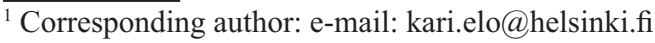


technological factors in cheese making affect coagulation (Lucey, 2002; Nájera et al., 2003).

Our studies have shown that in the Finnish Holstein-Friesian and in the Finnish Ayrshire about 12 and $30 \%$ of cows produce poorly coagulating milk (Tyrisevä et al., 2004), and about 1\% of Holstein-Friesian and 10\% of Ayrshire cows produce non-coagulating (NC) milk (Ikonen, 2000; Ikonen et al., 2004; Tyrisevä et al., 2004). Bittante et al. (2002) collected 6909 measurements of MCP from 517 Italian Friesian cows and observed that $19 \%$ of measurements were from NC-milk. Four Estonian dairy cattle breeds were studied by Kübarsepp et al. (2005) using 2161 milk samples from 87 cows. From the studied samples 103 samples (4.8\%) were NC-milk. A study by Wedholm et al. (2006) analysed coagulation properties of milk collected from 134 cows from the Swedish Red-and-White, the Swedish Holstein and the Danish Holstein-Friesian. More than $30 \%$ of cows milked poorly or non-coagulating milk (Wedholm et al., 2006). These studies suggest that the prevalence of poorly and noncoagulating milk should have significant economic outcome in cheese production.

In this study, our main aim was to analyse two candidate chromosomes, 24 and 28, affecting non-coagulation of milk in the Finnish Ayrshire. The genomic mapping in the rest of the chromosomes is in progress and our long-term objective is to characterize chromosomal regions and major genes underlying noncoagulating milk.

\section{MATERIAL AND METHODS}

We measured MCP from 4664 cows sired by 91 sires. One milk sample was collected per cow and milk coagulation time $(\mathrm{R})$, curd firming time $\left(\mathrm{K}_{20}\right)$ and curd firmness $\left(\mathrm{E}_{30}\right)$ were measured with computerized renneting meter as described by Ikonen et al. (2004).

Eighteen out of 91 sire families were selected for genomic mapping based on phenotypic distribution of MCP among daughters. Selected sires were expected to be heterozygotes for gene(s) underlying NC-milk because each sire had daughters producing both NC-milk and well-coagulating (E) milk. We pooled DNA samples of cows with NC- and E-milk using all families which had DNA extracted from blood samples. Pools included 17 sires and consisted of $33 \mathrm{NC}$ - and 49 E-daughters. Average number of cows per sire was 1.9 and 2.9 daughters for NCand E-pools, respectively. Using the two pools, all autosomes were analysed with 184 highly polymorphic microsatellite markers. The average number of markers per chromosome was six and the length of intervals between markers varied from 10 to $15 \mathrm{cM}$.

Based on differences between pools, we selected the two most promising chromosomes for genotyping in individual cows. Chromosomes 24 and 28 were 
studied using 14 microsatellite markers in daughter design with 18 sires and 480 daughters. Eighteen families consisted of $193 \mathrm{NC}$-cows and 287 E-cows (Table 1). Number of daughters in each family varied from 3 to 39 and 8 to 33 in NC- and E-groups (Table 1).

Table 1. The precorrected $\mathrm{E}_{30}$ values ${ }^{1}$ for all studied sire families grouped by daughters milking noncoagulating and well-coagulating milk

\begin{tabular}{|c|c|c|c|c|c|c|c|c|c|c|c|}
\hline \multirow{2}{*}{ Family } & \multirow{2}{*}{ Sire } & \multicolumn{5}{|c|}{ Non-coagulating (NC) } & \multicolumn{5}{|c|}{ Well-coagulating (E) } \\
\hline & & $\mathrm{n}$ & mean & $\min$ & $\max$ & Std & $\mathrm{n}$ & mean & $\min$ & $\max$ & Std \\
\hline 1. & Vakio & 39 & -21.5 & -29.8 & -14.4 & 3.8 & 33 & 11.9 & 1.3 & 21.2 & 4.4 \\
\hline 2. & Vara & 2 & -25.7 & -30.9 & -20.5 & 7.4 & 27 & 12.2 & 1.2 & 26.8 & 6.1 \\
\hline 3. & Vihtori & 17 & -22.5 & -28.5 & -14.3 & 3.5 & 16 & 11.6 & 1.0 & 29.7 & 6.4 \\
\hline 4. & Uklaus & 13 & -24.1 & -30.2 & -19.7 & 3.1 & 17 & 10.8 & 0.2 & 19.3 & 5.3 \\
\hline 5. & Uru & 14 & -22.2 & -31.3 & -16.4 & 4.0 & 18 & 12.6 & 4.8 & 18.7 & 3.7 \\
\hline 6. & Ugri & 5 & -24.9 & -30.1 & -21.1 & 3.8 & 16 & 12.6 & 3.8 & 21.7 & 5.1 \\
\hline 7. & Una & 11 & -21.8 & -29.4 & -15.2 & 4.7 & 16 & 13.9 & 5.0 & 23.3 & 4.6 \\
\hline 8. & Ulaus & 8 & -21.0 & -25.2 & -16.1 & 4.0 & 9 & 12.4 & 6.5 & 19.6 & 4.4 \\
\hline 9. & Unssi & 3 & -24.6 & -26.1 & -21.8 & 2.4 & 19 & 10.0 & 1.5 & 19.1 & 4.4 \\
\hline 10. & Upuli & 7 & -22.8 & -27.1 & -19.9 & 2.6 & 11 & 7.7 & 2.5 & 12.1 & 3.2 \\
\hline 11. & Uuttera & 6 & -23.7 & -30.4 & -18.0 & 4.4 & 8 & 12.2 & 8.0 & 16.9 & 3.6 \\
\hline 12. & Uisti & 10 & -23.0 & -31.4 & -18.6 & 4.2 & 17 & 12.1 & 5.4 & 24.6 & 4.6 \\
\hline 13. & Urhea & 11 & -25.7 & -30.8 & -0.2 & 3.3 & 11 & 8.0 & 3.0 & 15.9 & 4.9 \\
\hline 14. & Uranus & 9 & -24.0 & -28.7 & -17.4 & 3.5 & 13 & 10.3 & 3.1 & 21.1 & 4.9 \\
\hline 15. & Tunnus & 13 & -22.8 & -30.9 & -13.3 & 4.7 & 15 & 8.4 & 2.1 & 19.2 & 4.8 \\
\hline 16. & Solttu & 4 & -20.5 & -28.0 & -16.7 & 5.3 & 12 & 10.1 & 1.6 & 19.7 & 4.7 \\
\hline 17. & Sila & 14 & -21.3 & -28.7 & -13.8 & 4.8 & 19 & 11.3 & 2.6 & 20.1 & 4.8 \\
\hline 18. & Runsas & 7 & -22.6 & -25.9 & -16.4 & 3.2 & 10 & 14.8 & 8.3 & 21.2 & 3.9 \\
\hline \multicolumn{2}{|c|}{ Over all families } & 193 & -22.6 & -31.4 & -13.3 & 4.0 & 287 & 11.4 & -0.2 & 29.7 & 5.0 \\
\hline
\end{tabular}

${ }^{1} \mathrm{E}_{30}$ values are determined as curd firmness $30 \mathrm{~min}$ after addition of the clotting enzyme as described by Ikonen et al. (2004)

Curd firmness $\left(\mathrm{E}_{30}\right)$ was precorrected based on the results from a linear model including parity, lactation stage, measuring unit of a coagulation meter and age of milk sample as fixed effects and herd as a random effect. The precorrected $\mathrm{E}_{30}$ values were calculated from the total data set of 4664 cows. The values are given for all studied families in Table 1. Mean and standard deviation (in parenthesis) for precorrected $\mathrm{E}_{30}$ values of cows milking NC- and E-milk were -22.6 (4.0) and 11.4 (5.0) over all families in the data set (Table 1). The association between markers and pre-corrected $\mathrm{E}_{30}$ values was analysed using nonparametric interval mapping method (Coppieters et al., 1998). 


\section{RESULTS}

Information contents of microsatellite markers were high $(>0.8)$ along both chromosomes, except on one marker interval on chromosome 28 (0.2-0.8). The most significant association was found in family 4 on chromosome 24 at position $6 \mathrm{cM}$ (Figure 1A). The test statistic $(-\log (\mathrm{p})=2.23)$ had the experiment-wise significance level $\mathrm{P}=0.01$ (using Bonferroni correction for two chromosomes). The nearest marker was BM7151. The 90\% confidence interval was determined using 1000 bootstraps. According to the confidence interval, the most likely position of the locus (or loci) was from 0 to $14 \mathrm{cM}$ (Figure 1B).

A

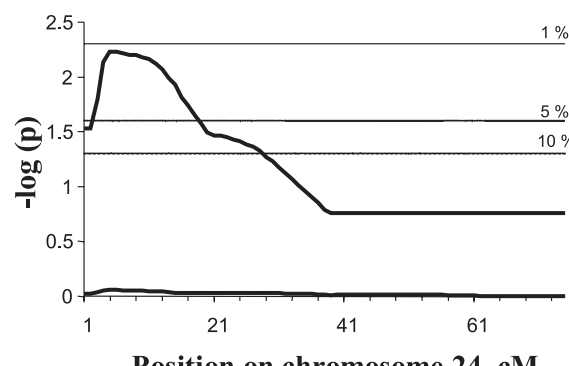

Position on chromosome 24, cM

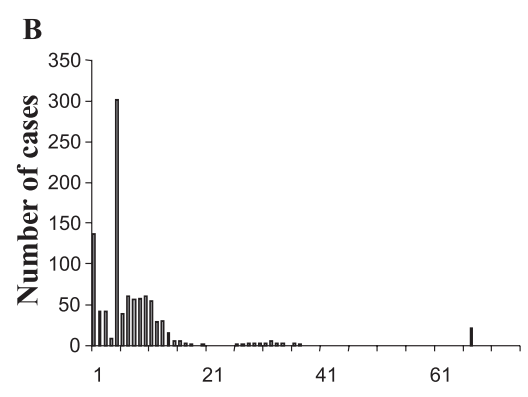

Position on chromosome 24, $\mathrm{cM}$

Figure 1. The most significant association between chromomal region and non-coagulation of milk was detected in one family on chromosome 24 . A. The test statistic approached $1 \%$ significance level in family 4 at position $6 \mathrm{cM}$ (upper curve). The test statistic was nonsignificant in across families analysis (lower curve). B. Based on the $90 \%$ confidence interval, the most likely position for a locus (or loci) is from 0 to $14 \mathrm{cM}$

\section{DISCUSSION}

Ikonen (2000) has studied possibilities to genetically improve MCP. Even $40 \%$ of the variation in MCP is additive genetic (Ikonen, 2000). This means that it is feasible to reliably estimate breeding values for MCP and improve it through selection of breeding animals. Unfortunately there are technical limitations in MCP measurements (Ikonen, 2000; Lucey, 2002) and currently it is not economically feasible to determine MCP as a part of routine milk recording.

Our previous studies have suggested that poorly coagulating milk and noncoagulating milk have different genetic basis (Ikonen, 2000; Ikonen et al., 2004). However, both poorly coagulating milk and non-coagulating milk have negative effects on cheese making properties when present in bulk milk. Because the incidence of cows with NC-milk is rather high in the Finnish Ayrshire, we expect that elimination of NCmilk from bulk milk could have significant positive effect in cheese production. 
In this study we detected the first chromosomal region that affects NC-milk in the Finnish Ayrshire. In our on-going genomic mapping we expect to find several other chromosomal regions and finally major genes that are underlying NC-milk. Characterized variation in major genes is the basis for development of DNA tests for detection of cows milking NC-milk and their male relatives. DNA tests should provide effective means to reduce the occurrence of NC-milk.

\section{CONCLUSIONS}

We detected a region on chromosome 24 affecting NC-milk in the Finnish Ayrshire. The region harbouring significant effect on NC-milk was found only in one family out of 18 studied sire families. Our current results from genomic mapping of DNA-pools support the view that there might be several genes affecting NC-milk in the Finnish Ayrshire.

\section{REFERENCES}

Bittante G., Marusi M., Cesarini F., Povinelli M., Cassandro M., 2002. Genetic analysis on milk rennetcoagulation ability in Italian Holstein cows. Proceedings of 7th World Congress on Genetics Applied to Livestock Production, Montpellier (France). CD-ROM Communication No. 09-03

Coppieters W., Kvasz A., Farnir F., Arranz J.-J., Grisart B., Mackinnon M., Georges M., 1998. A rank-based nonparametric method for mapping quantitative trait loci in outbred half-sib pedigrees: application to milk production in a granddaughter design. Genetics 149, 1547-1555

Eurostat, 2006. Food: From Farm to Fork Statistics. Eurostat, Health and Food Safety Unit. Luxembourg, pp. 121

Ikonen T., 2000. Possibilities of genetic improvement of milk coagulation properties of dairy cows. Academic Dissertation. University of Helsinki, Department of Animal Science. Publications No. 49. http://ethesis.helsinki.fi/julkaisut/maa/kotie/vk/ikonen/

Ikonen T., Morri S., Tyrisevä A.-M., Ruottinen O., Ojala M., 2004. Genetic and phenotypic correlations between milk coagulation properties, milk production traits, somatic cell count, casein content, and $\mathrm{pH}$ of milk. J. Dairy Sci. 87, 458-467

Kübarsepp I., Henno M., Viinalass H., Sabre D., 2005. Effect of $\kappa$-casein and $\beta$-lactoglobulin genotypes on the milk rennet coagulation properties. Agron. Res. 3, 55-64

Lucey J.A., 2002. Formation and physical properties of milk protein gels. J. Dairy Sci. 85, 281-294

Nájera A.I., Renobales de M., Barron L.J.R., 2003. Effects of $\mathrm{pH}$, temperature, $\mathrm{CaCl}_{2}$ and enzyme concentrations on the rennet-clotting properties of milk: a multifactorial study. Food Chem. 80, 345-352

Tyrisevä A.-M., Vahlsten T., Ruottinen O., Ojala M., 2004. Noncoagulation of milk in Finnish Ayrshire and Holstein-Friesian cows and effect of herds on milk coagulation ability. J. Dairy Sci. 87, 3958-3966

Wedholm A., Larsen L.B., Lindmark-Månsson H., Karlsson A.H., Andrén A., 2006. Effect of protein composition on the cheese-making properties of milk from individual dairy cows. J. Dairy Sci. 89, 3296-3305 